\title{
TRAIP wt Allele
}

National Cancer Institute

\section{Source}

National Cancer Institute. TRAIP wt Allele. NCI Thesaurus. Code C125107.

Human TRAIP wild-type allele is located in the vicinity of 3p21.31 and is approximately 28

$\mathrm{kb}$ in length. This allele, which encodes E3 ubiquitin-protein lig ase TRAIP protein, is involved in the ubiquitination of protein substrates. 